\title{
Antimicrobial and antioxidant properties of the crude peptide extracts of Galatea paradoxa and Patella rustica
}

\author{
Lawrence Sheringham Borquaye*, Godfred Darko, Edward Ocansey and Emmanuel Ankomah
}

\begin{abstract}
This study evaluated the antimicrobial and antioxidant activities of crude peptide extracted from Galatea paradoxa (G. paradoxa) and Patella rustica (P. rustica). The extracts were tested against eight strains of bacteria (Escherichia coli, Staphylococcus aureus, Bacillus subtilis, Salmonella typhi, Enterococcus feacalis, Klebseilla pneumoniae, Streptococcus pneumoniae, Pseudomonas aeruginosa) and one strain of fungi (Candida albicans) using agar well diffusion and broth dilution assays. The extracts from G. paradoxa demonstrated a high degree of activity against the bacteria strains but were inactive towards the fungus. P. rustica, however, showed a markedly higher antifungal activity but little antibacterial effect. The minimum inhibitory concentrations (MIC) of the extracts determined by the broth tube dilution assay were $17 \mathrm{mg} / \mathrm{mL}$ of G. paradoxa against the entire spectrum of microorganisms tested except for C. albicans which was $20 \mathrm{mg} / \mathrm{mL}$. The MIC of the extracts of P. rustica was $13 \mathrm{mg} / \mathrm{mL}$ against all the strains of microorganisms tested except for E. feacalis $(17 \mathrm{mg} / \mathrm{mL})$, K. pneumoniae $(17 \mathrm{mg} / \mathrm{mL})$ and C. albicans $(13 \mathrm{mg} / \mathrm{mL})$. Antioxidant activity using the 2,2-diphenyl-1-picrylhydrazyl (DPPH) assay showed scavenging ability on the DPPH radical was $56.77 \%$ at $0.39 \mathrm{mg} /$ $\mathrm{mL}$ for G. paradoxa and $79.77 \%$ at $0.39 \mathrm{mg} / \mathrm{mL}$ for P. rustica. The study indicates that the crude peptide extracts from the two molluscs have promising antimicrobial and antioxidant activities that can be harnessed as leads for potential bioactive compounds.
\end{abstract}

Keywords: Bacteria, Fungi, Bioactive compounds, Marine molluscs, Freshwater molluscs

\section{Background}

In recent years, there have been a rise in infectious disease cases all over the world. The emergence and/or reemergence of some of these infectious diseases such as the deadly Ebola viral disease (EVD) have had crippling economic and social impacts in countries affected. This, coupled to the fact that drug resistant pathogens are evolving at a much faster rate than new drugs are being discovered, has heightened the need to search for new classes of antimicrobial agents. The indiscriminate use of drugs to manage infectious diseases have not helped the situation. Many scientists and research programs are therefore prospecting for new antimicrobial agents from plants and animal sources.

*Correspondence: Isborquaye.sci@knust.edu.gh

Department of Chemistry, Kwame Nkrumah University of Science and Technology, Kumasi, Ghana
Marine invertebrates have proven to be rich sources of bioactive compounds with activities ranging from antimicrobial to antitumor (Martins et al. 2014; Leal et al. 2012; Thakur et al. 2005). Due to the fact that they exhibit broad spectrum antimicrobial activity, possess selective toxicities and are less prone to microbial resistance, antimicrobial peptides represent an exciting class of bioactive compounds that could potentially provide major reprieve for mankind in the efforts to curb/control infections. Because marine invertebrates rely solely on innate immune mechanisms for defense, they represent a potentially rich source for pharmacologically useful antimicrobial peptides (Otero-González et al. 2010).

Ghana possess a coastline of about $550 \mathrm{~km}$ with different types of aquatic habitat ranging from deep sea hydrothermal vent to intertidal regions. In addition, a number of freshwater habitats can be found all over the country. These aquatic habitats are home to a wide variety of invertebrates

\section{Springer}

(C) 2015 Borquaye et al. This article is distributed under the terms of the Creative Commons Attribution 4.0 International License (http://creativecommons.org/licenses/by/4.0/), which permits unrestricted use, distribution, and reproduction in any medium, provided you give appropriate credit to the original author(s) and the source, provide a link to the Creative Commons license, and indicate if changes were made. 
Table 1 Zone of Inhibition ( $\mathrm{mm}$ ) of extracts of Galatea paradoxa and Patella rustica against test microorganisms

\begin{tabular}{lcccc}
\hline & $\begin{array}{l}\text { Galatea } \\
\text { paradoxa }\end{array}$ & $\begin{array}{l}\text { Patella } \\
\text { rustica }\end{array}$ & $\begin{array}{l}\text { Positive control } \\
\text { (ciprofloxacin) }\end{array}$ & $\begin{array}{l}\text { Negative control } \\
\text { (25\% ACN/0.1 \% TFA) }\end{array}$ \\
\hline E. coli & $19.7 \pm 0.6$ & $0.0 \pm 0.0$ & $36.3 \pm 1.2$ & - \\
S. aureus & $20.0 \pm 0.0$ & $3.0 \pm 0.0$ & $14.7 \pm 0.6$ & - \\
B. subtilis & $20.3 \pm 0.6$ & $2.0 \pm 0.6$ & $19.0 \pm 1.0$ & - \\
S. typhi & $15.3 \pm 0.6$ & $2.0 \pm 1.0$ & $35.3 \pm 0.6$ & - \\
E. feacalis & $16.0 \pm 1.0$ & $15.0 \pm 1.0$ & $34.7 \pm 0.6$ & - \\
C. albicans & $0.0 \pm 0.0$ & $37.0 \pm 1.0$ & $41.0 \pm 2.0$ & - \\
K. pneumoniae & $14.7 \pm 0.6$ & $16.7 \pm 1.15$ & $35.0 \pm 0.0$ & - \\
S.pneumoniae & $20.3 \pm 0.6$ & $0.0 \pm 0.00$ & $15.0 \pm 1.7$ & - \\
P. aeruginosa & $20.3 \pm 1.5$ & $2.3 \pm 1.15$ & $35.3 \pm 1.2$ & \\
\hline
\end{tabular}

Values reported as mean \pm standard deviation. Mean of three experiments

Zone in $\mathrm{mm}$ indicates the distance from the border of the disc to the edge of the clear zone

ACN acetonitrile, TFA trifluoroacetic acid

(Ministry of Environment and Science 2002). Research geared towards the isolation of bioactive compounds from organisms thriving in these areas remain largely unexplored. Rather, a lot of attention has being focused on the terrestrial environment with most works dedicated to plant secondary metabolites (Adotey et al. 2012; Asomaning et al. 1999).

This paper reports on the antimicrobial and antioxidant activities of the crude peptide extracts of two molluscs, Galatea paradoxa (G. paradoxa) and Patella rustica ( $P$. rustica) obtained from the sea and a freshwater in Ghana respectively. G. paradoxa is a bivalve mollusc which belongs to the family Donacidae and is normally constrained to some few rivers in West Africa such as the River Volta in Ghana (Adjei-Boateng et al. 2012; Obirikorang et al. 2013). P. rustica is a gastropod belonging to the family Patellidae and can be found on rocky sea shorelines. Peptides from these two molluscs were extracted and tested against nine pathogenic microbes. The antioxidant activities of these extracts were also investigated.

\section{Results and discussion Antimicrobial activity}

In this work, the crude peptides from G. paradoxa and $P$. rustica were extracted via cold acetone precipitation. Following lyophilization, the crude peptide extracts were reconstituted in $25 \% \mathrm{ACN}$ in $0.1 \%$ TFA and used for the antimicrobial assay. Results are summarized in Table 1. Crude peptide extracts from G. paradoxa was observed to possess a high bactericidal activity with the highest zone of inhibition of $19.5 \mathrm{~mm}$ recorded against Escherichia coli, Staphylococcus aureus, Bacillus subtilis, Streptococcus pneumoniae and Pseudomonas aeruginosa. E. feacalis exhibited an inhibition zone of $16 \mathrm{~mm}$ while Salmonella typhi and Klebseilla pneumoniae recorded $15 \mathrm{~mm}$. Extracts from G. paradoxa however failed to inhibit the growth of the fungus Candida albicans. P. rustica crude peptide extracts were very effective in inhibiting the growth of the fungus, C. albicans, with an inhibition zone of $37 \mathrm{~mm}$. K. pneumoniae and E. feacalis recorded zones of inhibition of $16.5 \mathrm{~mm}$ and $15 \mathrm{~mm}$ respectively. The $P$. rustica extracts, however, was ineffective in inhibiting the growth of all other test microorganisms.

The results of the broth dilution test of the various extracts are presented in Table 2. The MICs of G. para$d o x$ and $P$. rustica towards the various test microorganisms ranged from 20 to $13 \mathrm{mg} / \mathrm{mL}$. G. paradoxa extracts recorded the highest $\mathrm{MIC}$ of $20 \mathrm{mg} / \mathrm{mL}$ towards $C$. albicans, with all other microorganisms giving an $\mathrm{MIC}$ of $17 \mathrm{mg} / \mathrm{mL}$. For P. rustica, an MIC of $13 \mathrm{mg} / \mathrm{mL}$ was recorded for C. albicans those of E. feacalis and K. pneumoniae were both $17 \mathrm{mg} / \mathrm{mL}$. All other microorganisms had an MIC of $20 \mathrm{mg} / \mathrm{mL}$.

In general, the crude peptide extracts of G. paradoxa was found to be the most active as evidenced by a higher AI of 2.1. P. rustica gave a modest AI of 1.2 indicating weak activity against tested microorganisms (Table 3). G. paradoxa extracts demonstrated a higher activity towards both Gram-positive and Gram-negative bacteria with AI of 2.5 and 2.3 respectively. P. rustica was much less active, giving an AI of 1 for both Gram-positive and Gram-negative bacteria. However, P. rustica extracts proved to be the most active antifungal agent, exhibiting an AI of 3 against fungi compared to G. paradoxa which had no activity (AI of 0 ). Comparison of the activity index of extracts against Gram-positive bacteria, Gram-negative bacteria and fungi is given in Fig. 1.

\section{Antioxidant assay}

As depicted in Fig. 2, the maximum scavenging ability of G. paradoxa was $56.77 \%$ at $0.39 \mathrm{mg} / \mathrm{mL}$ and that of $P$. rustica was $79.77 \%$ at the same concentration. Minima 
Table 2 Minimum inhibitory concentrations of extracts of Galatea paradoxa and Patella rustica against test microorganisms

\begin{tabular}{|c|c|c|c|c|c|c|c|c|c|c|c|c|c|c|}
\hline & \multicolumn{14}{|c|}{ Concentrations (mg/mL) } \\
\hline & \multicolumn{7}{|c|}{ Galatea paradoxa extracts } & \multicolumn{7}{|c|}{ Patella rustica extracts } \\
\hline & 23 & 20 & 17 & 13 & 10 & 7 & 3 & 23 & 20 & 17 & 13 & 10 & 7 & 3 \\
\hline E. coli & - & - & $* *$ & + & + & + & + & - & $* *$ & - & - & + & + & + \\
\hline S. aureus & - & - & $* *$ & + & + & + & + & - & $* *$ & - & - & + & + & + \\
\hline B. subtilis & - & - & $* *$ & + & + & + & + & - & $* *$ & - & - & + & + & + \\
\hline S. typhi & - & - & $* *$ & + & + & + & + & - & $* *$ & - & - & + & + & + \\
\hline E. feacalis & - & - & $* *$ & + & + & + & + & - & - & $* *$ & - & + & + & + \\
\hline C. albicans & - & $* *$ & + & + & + & + & + & - & - & - & $* *$ & + & + & + \\
\hline K. pneumoniae & - & - & $* *$ & + & + & + & + & - & - & $* *$ & - & + & + & + \\
\hline S.pneumoniae & - & - & $* *$ & + & + & + & + & - & $* *$ & - & - & + & + & + \\
\hline P. aeruginosa & - & - & $* *$ & + & + & + & + & - & $* *$ & - & - & + & + & + \\
\hline
\end{tabular}

$(+)$, indicates microbial growth; (-), indicates inhibition of microbial growth; $(* *)$, indicates MIC

Table 3 Antimicrobial index of crude peptide extracts of Galatea paradoxa and Patella rustica

\begin{tabular}{ll}
\hline & Antimicrobial index \\
\hline Galatea paradoxa & 2.1 \\
Patella rustica & 1.2 \\
\hline
\end{tabular}

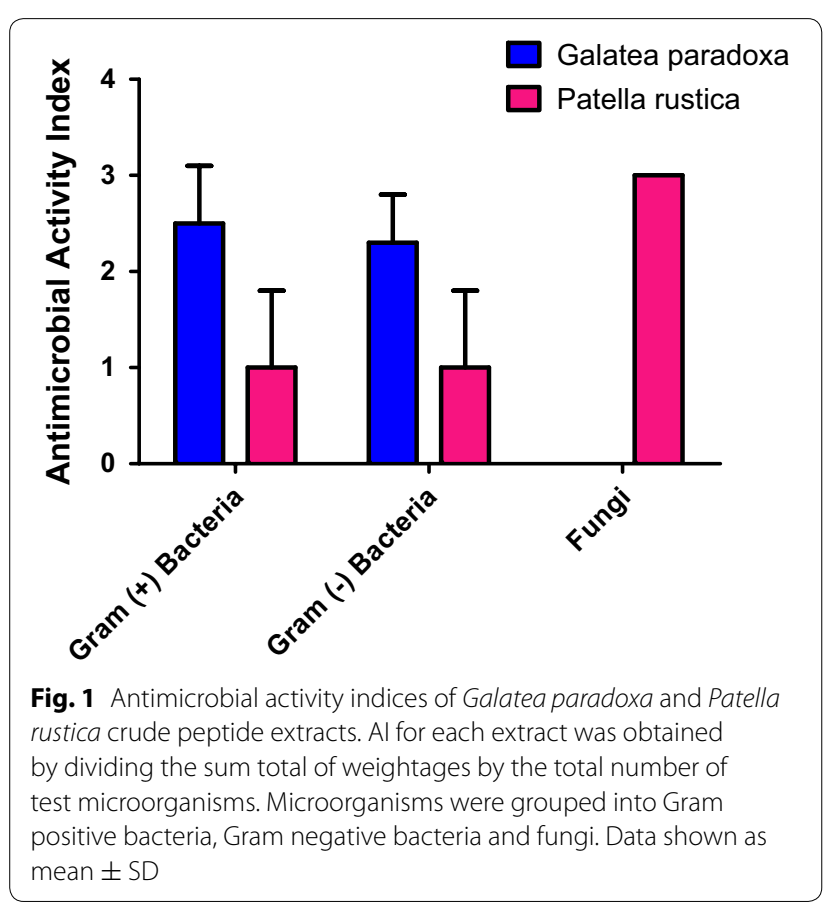

of 24.27 and $21.40 \%$ were recorded for G. paradoxa and P. rustica respectively at $0.0031 \mathrm{mg} / \mathrm{mL}$. Those for the standard ascorbic acid drug were 86.77 and $42.27 \%$ at 0.39 and $0.0031 \mathrm{mg} / \mathrm{mL}$ respectively.

\section{Discussion}

In this study, our goal was to identify potential sources of bioactive antimicrobial peptides for further purification. To do this, we examined the antimicrobial activity and antioxidant potential of the crude peptide extracts of two aquatic invertebrates, G. paradoxa and P. rustica. The results obtained thus far indicates that both molluscs are potentially good sources of antimicrobial peptides. Whereas extracts from G. paradoxa displayed impressive activity against both Gram-positive and Gram-negative bacteria, $P$. rustica extracts were much more ruthless towards fungi.

The antimicrobial tests were carried out against 4 Gram-positive bacteria (S. aureus, B. subtilis, E. feacalis, S. pneumoniae), 4 Gram-negative bacteria (E. coli, S. typhi, K. pneumoniae, P. aeruginosa) and one fungus (C. albicans). Extracts of G. paradoxa showed markedly high antibacterial inhibition towards E. coli, S. aureus, B. subtilis, S. pneumonia and P. aeruginosa. However, no activity was recorded against $C$. albicans. P. rustica extracts inhibited the growth of $C$. albicans at concentrations comparable to the positive control $(37 \mathrm{~mm}$ for $P$. rustica against 40 for the standard drug ciprofloxacin). The extracts from $P$. rustica were however, ineffective towards most of the pathogenic microorganisms used in this study. Based on the zones of inhibition, the AI computed suggested that G. paradoxa was a more promising source of antimicrobial peptides than $P$. rustica. This was evidenced by the fact that the AI of $P$. rustica extracts was 1.2 while that of G. paradoxa was 2.1. Since AMPs utilize different modes to inhibit Gram-positive bacteria, Gramnegative bacteria and fungi (Sathyan et al. 2014), it was important to compute AI of the various extracts against these classes of microorganisms. It was observed that $G$. 


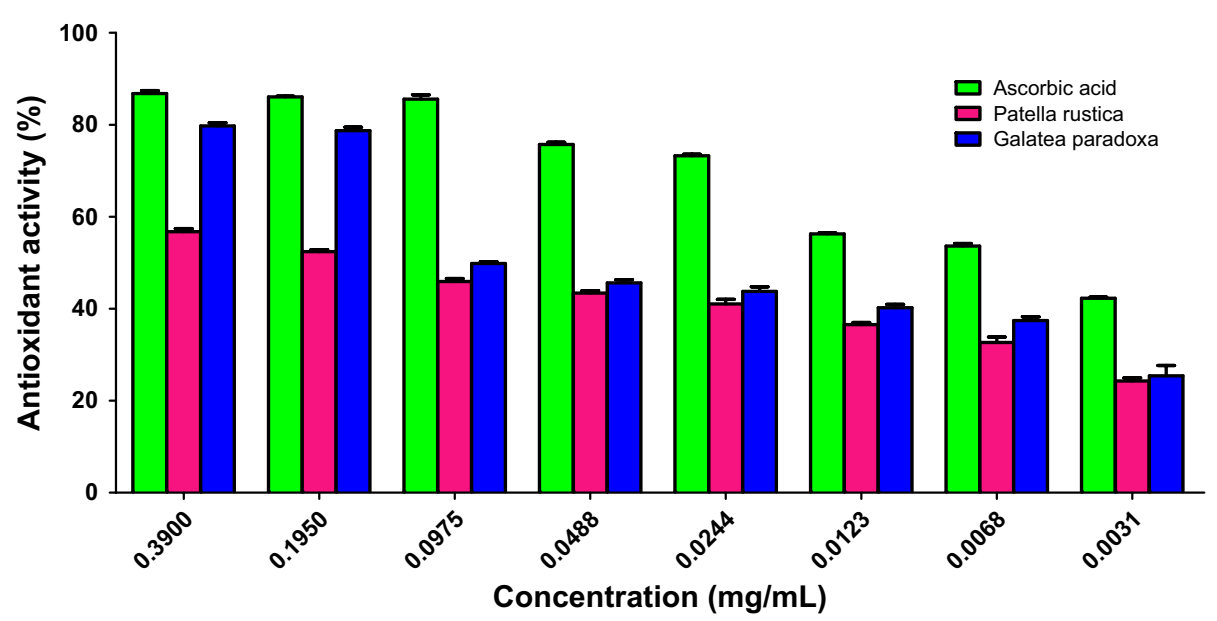

Fig. 2 Antioxidant activity of ascorbic acid and extracts of Galatea paradoxa and Patella rustica. The percent antioxidant activity was obtained at different concentrations of standard and test extracts. The percentage of DPPH scavenging was calculated as follows: DPPH radical scavenging activity $(\%)=[($ Absorbance of control - Absorbance of sample)/Absorbance of control $] \times 100$. Data shown as mean \pm SD of three separate experiments

paradoxa extracts were over $50 \%$ more active towards both Gram-positive and Gram-negative bacteria. P. rustica extracts, though confirmed their high antifungal activity with an AI of 3 towards fungi.

The activities of AMPs from some marine invertebrates have been previously documented. Work carried out on the molluscs, Mytilis edulis and Mytilis galloprovincialis resulted in the isolation of a number of AMPs (defensins, mytilin, mytimicin and myticin) (Chisholm et al. 2009; Mitta et al. 1999a, b; Miyata et al. 1989). In addition, the antimicrobial activities of the crude peptide extracts of 24 different molluscs have been reported by Sathyan et al. (2014). The antimicrobial activities of crude peptide extracts can be attributed to the presence of a number of different AMPs in the same sample. These AMPS could act in synergy or antagonistically. Isolation and characterization of these AMPs will go a long way in shedding light on this phenomenon.

The goal of this study was to characterize the antimicrobial and antioxidant properties of the crude peptide extracts of two Ghanaian molluscs. Review of literature has not shown any antimicrobial activity of the crude peptide extracts of $P$. rustica and G. paradoxa. Interestingly, crude peptide extracts that exhibit good antifungal activities are usually ineffective against any form of bacteria (Sathyan et al. 2014). The $P$. rustica extracts in this work followed such trend, displaying poor antibacterial activity but potent antifungal properties. This could be indicative of a different mode of action of AMPs towards different microorganisms (Sathyan et al. 2014; der Van Weerden et al. 2013).

While peptides have been documented to possess significant antioxidant activities (Suetsuna 2000; Mendis et al. 2005; Jung et al. 2004), most work on AMPs from marine molluscs do not consider this. In light of this, we investigated the antioxidant capacity of the crude peptide extracts from both G. paradoxa and P. rustica. When compared to the standard ascorbic acid, the percent antioxidant activity of the crude peptide extracts were lower. Both G. paradoxa and $P$. rustica extracts exhibited comparable activity at low concentrations. However, at high concentrations, the $P$. rustica extracts did a better job at scavenging the DPPH radicals. The lower percent antioxidant activities recorded might be due to the fact that the extracts used were in their crude, unpurified state. It is however difficult to draw any correlation between antioxidant capacity and antimicrobial activity based on these results.

\section{Conclusions}

In the present study, crude peptides extracted from two Ghanaian mollusks exhibited impressive antimicrobial activity against all nine pathogenic microorganisms tested. G. paradoxa extracts were found to be promising source of highly potent antibacterial agents whereas the $P$. rustica extracts were better antifungal agents. Both extracts demonstrated appreciable antioxidant activity that could be harnessed. The study confirms molluscs as potentially rich sources of antimicrobial and antioxidant peptides. Future work could focus on the isolation, purification and characterization of the bioactive components.

\section{Methods}

\section{Sample collection}

Galatea paradoxa and P. rustica samples used in this study were handpicked from their various habitats in February 2015. G. paradoxa was obtained from River Volta in the Volta Region of Ghana. P. rustica was collected 
from rocks in the sea at the Labadi Beach in the Greater Accra Region of Ghana. Samples were kept on ice and transported to the laboratory for analysis. Authentication of G. paradoxa and P. rustica samples used in the study were done at the Department of Fisheries and Marine Sciences, Kwame Nkrumah University of Science and Technology (KNUST), Kumasi-Ghana.

\section{Extraction}

The shells of the two species were removed and the tissue chopped into smaller pieces. The body tissue was then homogenized with five folds $(60 \mathrm{~mL}) \mathrm{w} / \mathrm{v} 10 \%$ acetic acid and kept for $12 \mathrm{~h}$ at $4{ }^{\circ} \mathrm{C}$. The extract obtained was centrifuged for $15 \mathrm{~min}$ at $4{ }^{\circ} \mathrm{C}$ and $3000 \mathrm{rpm}$ (TD3 Tabletop centrifuge, China) and the supernatant collected. Ice cold acetone $(25 \mathrm{~mL})$ was then added and the entire mixture kept at $4{ }^{\circ} \mathrm{C}$ for $12 \mathrm{~h}$. The precipitate formed was collected and freeze dried (Labconco, Kansas City) for $1 \mathrm{~h}$. It was then reconstituted in $25 \%$ acetonitrile( $\mathrm{ACN})$ prepared in $0.1 \%$ trifluoroacetic acid (TFA) (Sathyan et al. 2014).

\section{Antimicrobial assay Microbial cultures}

Eight strains of bacteria and one fungal strain were used to assess the antimicrobial properties of the crude extracts. The Gram negative bacteria Escherichia coli ( $E$. coli), Salmonella typhi (S. typhi), Klebseilla pneumoniae (K. pneumoniae) and Pseudomonas aeruginosa (P. aureginosa) and Gram positive bacteria Staphylococcus aureus (S. aureus), Bacillus subtilis (B. subtilis), Enterococcus feacalis (E. feacalis) and Streptococcus pneumoniae (S. pneumoniae) were used as test microorganisms. The fungal strain used for the antimicrobial assay was C. albicans (C. Albicans). All the microbial strains were obtained from the Department of Pharmaceutical Chemistry, College of Health Science, KNUST, Kumasi, Ghana.

\section{Inoculum preparation}

Sabouraud growth media was prepared and sterilized in an autoclave at $121{ }^{\circ} \mathrm{C}$ for $15 \mathrm{~min}$. All 9 microbes were individually incubated at $37^{\circ} \mathrm{C}$ for $18 \mathrm{~h}$ and $72 \mathrm{~h}$ in case of the fungus.

\section{Diffusion well assay}

The antimicrobial activities of the crude extracts were evaluated by diffusion well assay. The nine microorganisms were cultured on nine different agar plates with three wells in each plate. $20 \mu \mathrm{L}$ portions of each extract was pipetted into each well. Ciprofloxacin was used as the standard antibiotic (positive control) while $0.1 \%$ TFA in $25 \% \mathrm{ACN}$ was used as negative control. The plates were incubated at $30{ }^{\circ} \mathrm{C}$ for $24 \mathrm{~h}$. The zone of inhibition was measured in millimeters $(\mathrm{mm})$ as the distance from the border of the disc to the edge of the clear zone. The assay was repeated three times and the averages of the three experiments taken.

\section{Minimum inhibitory concentration}

The minimum inhibitory concentration (MIC) was determined by broth micro dilution assay. Nutrient broth, microorganisms and the extract was mixed up to a final volume of $200 \mu \mathrm{L}$ using a 96 well microtiter plate. Serial dilutions of the extracts were poured into subsequent wells. Across the rows for each microtiter plate, $10 \mu \mathrm{L}$ of the nine different test organisms were added. This was followed by addition of $100 \mu \mathrm{L}$ of nutrient broth to each well. Finally, sterile water was added to top up to the $200 \mu \mathrm{L}$ mark. The plates were then covered and incubated at $30^{\circ} \mathrm{C}$ for $24 \mathrm{~h}$. After $24 \mathrm{~h}$ the plates were removed and a solution of 3-(4,5-dimethylthiazol-2-yl)-2,5-diphenyltetrazolium bromide (MTT) was added to each well. The wells that changed colour to violet are indicative of the growth of microorganisms, whiles those that remains unchanged indicated inhibition of microbial growth by the crude extracts.

\section{Antimicrobial activity index}

For each crude peptide extract, the antimicrobial index (AI) were calculated as the average of the antimicrobial activity obtained against all test microorganisms. Weightages were assigned to the activity of extracts against each test organism as follows; a weightage of one (1) for zone of inhibition up to $10 \mathrm{~mm}$, two (2) for zone of inhibition ranging from 11 to $20 \mathrm{~mm}$, three (3) if the zone of inhibition was greater than $20 \mathrm{~mm}$ and zero (0) for no antimicrobial activity. The AI was obtained by dividing the sum total of weightages obtained by each crude extract by the total number of test microorganisms. Separate AI was calculated for Gram positive bacteria, Gram negative bacteria and fungi to compare the activity of the two extracts (Ghosh et al. 2008; Sathyan et al. 2014).

\section{Antioxidant activity assay}

The free radical scavenging capacity of the extracts was determined using the 2, 2-diphenyl-1-picrylhydrazyl (DPPH) assay. Serial dilutions of extracts were prepared in different test tubes and freshly prepared DPPH solution added to a final volume of $3 \mathrm{~mL}$. After $30 \mathrm{~min}$, the absorbance was read at $517 \mathrm{~nm}$ using a UV-Visible spectrophotometer (Perkin Elmer Lambda 35). Ascorbic acid was used as reference standard. Control sample was prepared containing the same volume without any extracts. Absorbance of freshly prepared DPPH was also read. Methanol was used as the blank. 


\section{Abbreviations}

ACN: acetonitrile; Al: antimicrobial index; AMP: antimicrobial peptide; DPPH: 2,2-diphenyl-1-picrylhydrazyl; EVD: Ebola viral disease; MIC: minimum inhibitory concentration; MTT: 3-(4,5-dimethylthiazol-2-yl)-2,5-diphenyltetrazolium bromide; SD: standard deviation; TFA: trifluoroacetic acid.

\section{Authors' contributions}

LSB and GD conceived the study and helped draft the manuscript. All experiments were designed by LSB, GD, EO and EA. Samples were collected by EO. $E O$ and EA carried out all the experiments. All authors read and approved the final manuscript.

\section{Compliance with ethical guidelines}

\section{Competing interests}

We have read and understood SpringerPlus' policy on declaration of interests and all authors declare that we have no competing financial, professional, or personal interests that might have influenced the performance or presentation of the work described in this manuscript.

Received: 16 July 2015 Accepted: 21 August 2015

Published online: 17 September 2015

\section{References}

Adjei-Boateng D, Agbo NW, Agbeko NA, Obirikorang KA, Amisah S (2012) The Current State of the Clam, Galatea Paradoxa, Fishery at the Lower Volta River, Ghana. IIFET Tanzan Proc 6:1-12

Adotey JPK, Adukpo GE, Opoku Boahen Y, Armah FA (2012) A review of the ethnobotany and pharmacological importance of Alstonia boonei De Wild (Apocynaceae). ISRN Pharmacol 1-9

Asomaning WA, Otoo E, Akoto O, Oppong IV, Addae-Mensah Ivan, Waibel R, Achenbach H (1999) Isoflavones and coumarins from Miletia thonningii. Phytochemistry 51(7):937-941

Chisholm June RS, Smith VJ (2009) Antibacterial activity in the haemocytes of the shore crab, Carcinus maenas. J Marine Biol Assoc U K. Cambridge University Press. 72(03):529-37

der Van Weerden, Nicole L, Bleackley MR, Anderson MA (2013) Properties and mechanisms of action of naturally occurring antifungal peptides. Cell Mol Life Sci 70(19):3545-3570

Ghosh S, Subudhi E, Nayak S (2008) Antimicrobial assay of Stevia rebaudiana bertoni leaf extracts against 10 pathogens. Int J Integr Biol 2(1):1-5
Jung W-K, Rajapakse N, Kim S-K (2004) Antioxidative activity of a low molecular weight peptide derived from the sauce of fermented blue mussel, Mytilus edulis. Eur Food Res Technol 220(5-6):535-539

Leal MC, Madeira C, Brandão CA, Puga J, Calado R (2012) Bioprospecting of marine invertebrates for new natural products - a chemical and zoogeographical perspective. Molecules 17:9842-9854

Martins A, Vieira H, Gaspar H, Santos S (2014) Marketed marine natural products in the pharmaceutical and cosmeceutical industries: tips for success. Marine Drugs 12:1066-1101

Mendis E, Rajapakse N, Byun H, Kim S-K (2005) Investigation of jumbo squid (Dosidicus gigas) skin gelatin peptides for their in vitro antioxidant effects. Life Sci 77(17):2166-2178

Ministry of Environment and Science, Republic of Ghana (2002) National Biodiversity Strategy for Ghana. National Biodiversity Strategy for Ghana 1-62

Mitta G, Vandenbulcke F, Hubert F, Roch P (1999a) Mussel defensins are synthesised and processed in granulocytes then released into the plasma after bacterial challenge. J Cell Sci 112(23):4233-4242

Mitta G, Hubert Florence, Noel T, Roch P (1999b) Myticin, a novel cysteine-rich antimicrobial peptide isolated from haemocytes and plasma of the mussel Mytilus galloprovincialis. Eur J Biochem 265(1):71-78

Miyata T, Tokunaga F, Yoneya T, Yoshikawa K, Iwanaga S, Niwa M, Takao T, Shimonishi Y (1989) antimicrobial peptides, isolated from horseshoe crab hemocytes, tachyplesin II, and polyphemusins I and II: chemical structures and biological activity. J Biochem 106(4):663-668

Obirikorang KA, Amisah S, Adjei-Boateng D (2013) Habitat Description of the Threatened Freshwater Clam, Galatea Paradoxa (Born 1778) at the Volta Estuary, Ghana. Curr World Environ 8(3):331-339

Otero-González AJ, Magalhães BS, Garcia-Villarino M, López-Abarrategui C, Sousa DA, Dias SC, Franco OL (2010) Antimicrobial peptides from marine invertebrates as a new frontier for microbial infection control. FASEB J 24:1320-1334

Sathyan N, Chaithanya ER, Anil Kumar PR, Sruthy KS, Philip R (2014) Comparison of the antimicrobial potential of the crude peptides from various groups of marine molluscs. Int J Res Marine Sci 3(2):16-22

Suetsuna K (2000) Antioxidant peptides from the protease digest of Prawn (Penaeus japonicus) muscle. Marine Biotechnol (New York, N.Y.) 2(1):5-10

Thakur NL, Thakur AN, Müller WEG (2005) Marine natural products in drug discovery. Natural Product Radiance 4(471):471-477

\section{Submit your manuscript to a SpringerOpen ${ }^{\circ}$ journal and benefit from:}

- Convenient online submission

- Rigorous peer review

- Immediate publication on acceptance

- Open access: articles freely available online

- High visibility within the field

- Retaining the copyright to your article

Submit your next manuscript at $\boldsymbol{\wedge}$ springeropen.com 